\title{
AN ANALYSIS ON INDONESIAN ELT TEXTBOOK FOR GRADE XI FROM THE PERSPECTIVE OF SLA PRINCIPLES USING LITTLEJOHN'S FRAMEWORK
}

\author{
Christina Atika Yulina \\ christinatikaa@gmail.com \\ English Language Studies, Universitas Sanata Dharma
}

\begin{abstract}
This paper outlines a procedure for language textbook analysis from the perspective of second language acquisition (SLA) principles using a minimally modified version of Littlejohn's threelevel framework by Guilloteaux as a preliminary procedure to textbook evaluation for selection. The aim is to analyze to what extent does Indonesian ELT textbook for grade XI reflects the universal SLA principles. The universal SLA principles used as material analysis criteria in this paper were drawn from the literature selected by Guilloteaux. This analysis revealed that the Indonesian ELT textbook by the Ministry of Education and Culture reflected SLA principles closely. Although only in-use evaluation can determine the extent to which this textbook actually supports language acquisition, the evidence suggests that the textbook is potentially supportive to English language learning.
\end{abstract}

Keywords: textbook, textbook analysis, second language acquisition

\section{INTRODUCTION}

Many EFL/ESL teachers use textbooks in class for the instructional materials. In practice, the use of textbooks is known to give benefits for both teachers and students (Hutchinson and Torres, 1994). For teachers, textbooks may provide the ideas and the instruction on how to plan and teach lessons. For the learners, textbooks may provide the basic content, the instructions of the materials, and the practices as the major or the main source for the lesson. Although nowadays internet provides some situations that serve much language input and space to practices outside the classroom, much of the language teaching that occurs throughout the world today could not take place without the extensive use of commercial textbooks (Richards, 2001) since textbooks seem having more directed instructional materials that can be the best main guide for English learning and teaching activities. In other word, textbooks provide more structured program that have a central core and have been systematically planned and developed; and provide more standardized instruction that ensure the students in different classes receive similar content and therefore can be assessed or tested in the similar way (Richards, 2001). 
Textbooks quality can affect the learning experiences of many students (Guilloteaux, 2012) although there is almost no textbook that is definitely suitable for all teachers and students (Tomlinson, 1998; Richards, 2001). Thus, textbooks selection for ELT is important. Both the benefits and limitations of the use of textbooks needs to be considered, and if the textbooks that are being used in a program are judged to have some negative consequences, remedial action should be taken, e.g. by adapting or supplementing books or by providing appropriate guidance and support for teachers in how to use them appropriately (Richards, 2001). However, material textbook selection is not always efficient since it typically relies on the predictive evaluation (Ellis, 1997 as mentioned in Guilloteaux, 2012).

Cook (2008) mentioned that using the principles from second language acquisition (SLA) may become a potential avenue for increasing the efficiency of the predictive evaluation since it can reveal some strengths and weaknesses in the construction of the language material. As mentioned by Guilloteaux, several publications in the materials development literature have suggested SLA-based principles for materials design (e.g., Cook 1998; Richards 2006; Tomlinson 1998, 2010, 2011). However, the use of instructed SLA research output is still an underexplored area in materials evaluation. Guilloteaux then offered a more efficient procedure for the selection of textbooks (used here interchangeably with learning/teaching materials) by introducing a preliminary materials analysis phase into materials evaluation. It uses a recognized task analysis schedule (Littlejohn 1998, 2011) as an operational framework to evaluate whether textbooks reflect universal principles representing a spectrum of competing SLA theories.

This paper aims to see to what extent does Indonesian ELT textbook for grade XI reflect the universal SLA principles. The textbook analyzed by the researcher was the third edition of English textbook for Grade XI published by Pusat Kurikulum dan Perbukuan, Balitbang, Kemendikbud (Indonesian Ministry of Education and Culture) in 2017. Since the textbook was specifically arranged to implement the curriculum of 2013, the textbook is used in most of senior high school in Indonesia. Besides, this textbook is free downloaded. It is easy for everyone to access this textbook.

\section{THEORETICAL FRAMEWORK Material Selection}

The textbook is an important component in most language programs. Thus, a quality textbook should be a model of good teaching (Newton and Newton 2009) and should facilitate students' language learning (Cook 1998; Tomlinson 2008, 2011; Waters 2009). Although the development of new technologies that allow for higher quality teacher-generated material, the demand for textbooks still continues to grow since the curriculum in Indonesia is always updated. Thus, both the government and the publishing industry responds with new series and textbooks in a certain range of time. 
Researchers have advocated a variety of approaches to textbook selection (Cunningsworth, 1984), but in practice, the process is often based on personal preference and may be affected by factors unrelated to pedagogy (Garinger, 2002). Even if practitioners use one of the numerous checklists and questionnaires developed to analyze and evaluate textbooks, the selected materials may still not provide optimal conditions for language learning. This is because those instruments tend to be subjective and difficult to quantify -hence unreliable (Littlejohn, 1992); and often rely on many vague that is locally specific, and sometimes based on dogmatic criteria only, include learners' needs, goals, learning styles, and proficiency levels; classroom contexts and processes; the potential of the materials for generating motivation, variety, and interest; and language teaching methods (Rubdy 2003).

\section{Material Analysis and SLA}

One way of making textbook selection more objective is to build a materials analysis phase into predictive evaluation (Guilloteaux, 2012). Tomlinson (2003) distinguishes between materials evaluation and materials analysis. The objective of materials evaluations tends to be subjective it aims to predict or make judgments about the effects of the materials to their intended users. Meanwhile, material analysis tends to be more objective because it attempts to describe materials as they are. Regrettably, many checklists mix evaluation-type items (i.e., unipolar or bipolar items) and analysis items (i.e., yes/no questions, frequency counts) (Guilloteaux, 2012). Guilloteaux mentioned one exception framework for material analysis: it is Littlejohn's threelevels framework (1998, 2011). As mentioned by Guilloteaux (2012), level 1 assesses the physical aspects of the materials and the main instructional steps within a typical unit; level 2 analyzes each textbook activity in detail; level 3 requires deduction of what is implied regarding the syllabus and the teachers' and learners' roles. Level 2 focuses on activities as units of analysis. It enables analysts to describe every teaching/ learning activity contained in a textbook. There are three parts of level 2 in Littlejohn's framework: (a) What is the learner expected to do? (deals with learners' role, activity focus, and broad cognitive processes involved); (b) Who with? (deals with participation structure/ interaction); (c) With what contents? (deals with input/output types). These three areas can be informed by SLA research and can serve to assess the extent to which materials may support students' language learning (Guilloteaux, 2012).

SLA researchers have urged caution in applying SLA-derived principles to pedagogy (see Ellis 2005). Guilloteaux mentioned that it has been suggested that SLA-based principles can be employed as predictions to inform pedagogical decisions made in or for the classroom (e.g., Ellis, 1997; Waters, 2009). It means that SLA principles can be used to explain and critique materials design features by identifying the extent to which materials are "in harmony with how learners learn'" (Ellis, 1997). Table 1 represents the Guilloteaux' attempt to select universal SLA-based principles. The selection represents a synthesis of the main SLA principles proposed by Cook (1998), Ellis (2005), Richards (2006), Tomlinson (2010), and Tomlinson and Masuhara (2010). These principles selected by Guilloteaux are used to interpret the results of materials analyses 
carried out with Littlejohn's $(1998,2011)$ scheme for the analysis of the activities in textbook. The principles are selected with two approach from psycholinguistic and sociolinguistic viewpoints. First, the selection aimed to embody the core elements presently known as representing potentially favorable and unfavorable conditions for instructed L2 learning from a psycholinguistic viewpoint that views "the learner as operating and developing a relatively autonomous L2 system, and sees interaction as a way of feeding that system with more or less fine-tuned input data"' (Mitchell and Myles 2001, p. 22 as mentioned in Guilloteaux, 2012). A sociolinguistic perspective is considered in the selection to be more relevant to the second language learning contexts (e.g., ESL) than to foreign language classrooms (e.g., EFL contexts) where learners often share the same first language and interact with other learners of similar levels in the L2, and where the teacher may not even be an expert L2 user (Guilloteaux, 2012). In contrast, a sociolinguistic SLA views language learning essentially as a process in which "both the identity of the learner, and their language knowledge, are collaboratively constructed and reconstructed in the course of interaction" (Mitchell and Myles, 2001, as mentioned in Guilloteaux, 2012).

Table 1 SLA Principles Selected by Guilloteaux (2012)

Proponent Principles

\begin{tabular}{|c|c|}
\hline Proponent & Principles \\
\hline \multicolumn{2}{|r|}{ What supports language acquisition } \\
\hline (Ellis, 2005) & $\begin{array}{l}\text { A predominant focus on meaning: mostly pragmatic meaning (i.e., what language forms } \\
\text { convey in communication); but also semantic meaning (i.e., what language conveys, } \\
\text { irrespective of context, when language is treated as an object of study). }\end{array}$ \\
\hline $\begin{array}{l}\text { (Cook 1998; DeKeyser } \\
\text { 2010; Ellis; Richards 2006) }\end{array}$ & $\begin{array}{l}\text { Meaningful practice of unanalyzed formulaic expressions (as in a notional-functional } \\
\text { approach), especially in the early stages: The rote-memorized patterns will be available for } \\
\text { analysis later when the learners are developmentally ready, thereby contributing to the ability } \\
\text { to use language fluently and accurately. }\end{array}$ \\
\hline (Ellis) & $\begin{array}{l}\text { Participation in communicative activity (Tomlinson and Masuhara 2010) to boost learners' } \\
\text { implicit knowledge of the L2. }\end{array}$ \\
\hline (Ellis) & $\begin{array}{l}\text { Focus on form (e.g., corrective feedback) and intensive focus on pre-selected linguistic } \\
\text { forms, by an inductive and/or deductive approach. }\end{array}$ \\
\hline $\begin{array}{l}\text { (Ellis 2005; Tomlinson } \\
\text { 2010) }\end{array}$ & Exposure to extensive language in use. \\
\hline (Ellis; Tomlinson 2010) & $\begin{array}{l}\text { Opportunities for free production of output of a clause or more, but not the type produced } \\
\text { during controlled practice exercises. }\end{array}$ \\
\hline $\begin{array}{l}\text { (Lantolf 2000; Long 1996; } \\
\text { Ellis), }\end{array}$ & $\begin{array}{l}\text { Pair and group activities that promote interaction in the L2 } \\
\text { but excessive use of the L1 in monolingual contexts may actually hinder it. }\end{array}$ \\
\hline $\begin{array}{l}\text { (Ellis; Richards 2006; } \\
\text { Tomlinson and Masuhara } \\
\text { 2010) }\end{array}$ & $\begin{array}{l}\text { Engaging learners cognitively in a variety of a learning activities and through high } \\
\text { instructional clarity, achievable challenges, awareness of different learning styles, and } \\
\text { strategy training, including experiential and learner training activities. }\end{array}$ \\
\hline $\begin{array}{l}\text { (Richards 2006; Tomlinson } \\
\text { and Masuhara 2010) }\end{array}$ & $\begin{array}{l}\text { Engaging learners affectively by providing relevant and interesting contents, and giving } \\
\text { opportunities to express own meanings and choose own topics. }\end{array}$ \\
\hline \multicolumn{2}{|r|}{ What seems to be of limited use in language acquisition } \\
\hline & $\begin{array}{l}\text { Mechanical drills requiring exclusive attention to form divorced } \\
\text { from meaning (De Keyser 2010); mechanical drills may even be } \\
\text { of no use at all (Wong and Van Patten 2003) }\end{array}$ \\
\hline
\end{tabular}

\section{METHOD \\ Sample}

The textbook analyzed in this paper is English textbook for Senior High School Grade XI (year 2) established by the Ministry of Education and Culture entitled Bahasa Inggris. The 
textbook is the third edition of English textbook for Grade XI published by Pusat Kurikulum dan Perbukuan, Balitbang, Kemendikbud (Indonesian Ministry of Education and Culture) in 2017. The book was selected because it was specifically arranged to implement the curriculum of 2013 by the ministry of education and culture, and the textbook is used in most of senior high school in Indonesia.

\section{Material Analysis Instrument}

A minimally modified version of the second level of Littlejohn's $(1998,2011)$ materials analysis framework used by Guilloteaux was used to analyze the materials in this paper, which concerns what learners are expected to do during tasks. This means that the focus of this paper is the level 2 of Littlejohn's framework that focuses on activities as units of analysis. According to Littlejohn (1992), tasks are defined as any activity that facilitates learning. Those include three elements: (1) a process through which the learners are expected to go; (2) a mode of classroom participation concerning with whom the learners are to work; (3) content upon which learners are to engage.

\section{Data Processing}

The author conducted the analysis of the materials independently. Results was presented in tables and the criteria were finalized and illustrated with typical examples, resulting in the framework finally used in this paper. There are three aspects used to analyze the materials/activities in the textbook -which were from three important parts of level 2 in Littlejohn's framework: (a) What is the learner expected to do? (deals with learners' role, activity focus, and broad cognitive processes involved); (b) Who with? (deals with participation structure/ interaction); (c) With what contents? (deals with input/output types). These three areas can be informed by SLA research and can serve to assess the extent to which materials may support students' language learning (Guilloteaux, 2012). For the purpose of assessing the book, the activities were awarded plus points (+) when features were in line with SLA principles, or minus points (-) when they were not. The activities in the textbook were analyzed and categorized based on the three parts of level 2 in Littlejohn's framework.

\section{FINDING AND DISCUSSION}

This book consists of eight units and seven enrichment chapters. All the instructions in the book use the L2 (English). The researcher only analyzed the eight units that consists of seven subunits in each unit (except for unit 7), namely pre-activity, building block, let's practice, active conversation, writing connection, let's create, and formative assessment. Each sub-unit has several activities (look at Table 2). In total, there are 106 tasks from unit 1 up to unit 8: 20 activities for pre-activity, 8 activities for building block, 16 activities for let's practice, 13 activities for active conversation, 7 activities for writing connection, 18 activities for let's create and 24 activities for formative assessment. 
Table 2 Task and Activities in each Sub-unit

\begin{tabular}{|c|c|c|c|c|c|c|c|c|c|}
\hline \multirow[t]{2}{*}{ Sub-unit } & \multicolumn{9}{|c|}{ Activity } \\
\hline & $\begin{array}{l}\text { Unit } \\
1\end{array}$ & $\begin{array}{l}\text { Unit } \\
2\end{array}$ & $\begin{array}{l}\text { Unit } \\
3\end{array}$ & $\begin{array}{l}\text { Unit } \\
4\end{array}$ & $\begin{array}{l}\text { Unit } \\
5\end{array}$ & $\begin{array}{l}\text { Unit } \\
6\end{array}$ & $\begin{array}{l}\text { Unit } \\
7\end{array}$ & $\begin{array}{l}\text { Unit } \\
8\end{array}$ & TOTAL \\
\hline Pre-activity & 2 & 2 & 2 & 2 & 2 & 2 & 6 & 2 & 20 \\
\hline $\begin{array}{l}\text { Building } \\
\text { Block }\end{array}$ & 1 & 1 & 1 & 1 & 1 & 1 & 1 & 1 & 8 \\
\hline $\begin{array}{l}\text { Let's } \\
\text { Practice }\end{array}$ & 4 & 1 & 2 & 1 & 2 & 4 & - & 2 & 16 \\
\hline $\begin{array}{l}\text { Active } \\
\text { Conversation }\end{array}$ & 1 & 1 & 1 & 2 & 2 & 2 & 2 & 2 & 13 \\
\hline $\begin{array}{l}\text { Writing } \\
\text { Connection }\end{array}$ & 1 & 1 & 1 & 1 & 1 & 1 & - & 1 & 7 \\
\hline Let's Create & 4 & 4 & 3 & 2 & 2 & 1 & - & 2 & 18 \\
\hline $\begin{array}{l}\text { Formative } \\
\text { Assessment }\end{array}$ & 3 & 3 & 3 & 3 & 3 & 3 & 3 & 3 & 24 \\
\hline & & & & AL & & & & & 106 \\
\hline
\end{tabular}

A plus sign (+) indicated that the task/activity facilitates instructed language learning for the students to interact in and with the L2. Meanwhile, the minus sign (-) indicated that the task/activity requires no production of output of the L2 or no overt behavioral demonstration of engagement with input should be avoided -this is because that the activity/task make the students may simply let the L2 wash over them as noise and not learn from it without any output or L2 production.

\section{What is the learner expected to do?}

Table 3 shows the learners' expected role during the tasks in all units and their sub-units. Part $\mathrm{A}$ is about the turn taking done by the students, part B is the focus given by the tasks/activities (whether the activities focus on language system, meaning, or meaning/form relationship), and part $\mathrm{C}$ is operation done by the students. For part $\mathrm{A}$, the activities and tasks provided in the book are $41.51 \%$ facilitate the students to initiate language; and $29.25 \%$ of the tasks take place the learners in a respond position. $20.75 \%$ of the tasks do not required any action -it means that the activities done by the students are only involving receptive skills: reading or listening activities. $29.25 \%$ of the tasks and activities in the book focus on the language system and $34.91 \%$ focus on the meaning. However, focusing on forms relationship seems to have been considered of more importance by the book (63.21\%). Focus on the language system was shown through practicing and applying the language system forms/patterns and rules tasks. Focus on the meaning was shown in the comprehension exercises but without any extended L2 output. Meanwhile, focus on the meaning relationship was shown through consciousness-raising activity by preparing a report or performance for presentation to the class -that is more contextual in L2 production.

For the operation done by the students, the features attracting the highest percentages in this section involve those related to comprehension in sub-unit let's practice, active conversation, writing connection and let's create (see appendix 1). Theories of comprehension in those sub- 
units stress the importance of helping students understand spoken or written texts by having them relate their schematic knowledge to new information contained in a text, or by expanding that knowledge if necessary. Moreover, more than a half from the whole tasks in the book apply general knowledge that use another information in other subject $(60.38 \%)$; and $56.60 \%$ apply language rules. Overall, the book appears to engage learners cognitively in more varied ways (e.g., meaningful drills and repetition-type tasks followed by transformation and expansion); but the book is low in tasks that require negotiating $(3,77 \%)$ and decoding meaning in L1 (only $2,83 \%$ ). The activities that involved the students to attend to examples is also low (only 14.15\%).

Table 3 The Learners' Expected Role during Tasks

I. What is the learner expected to do?

\begin{tabular}{|c|c|c|c|}
\hline & Aspect & Total & Percentage \\
\hline \multirow[t]{4}{*}{$\mathbf{A}$} & TURN TAKE & & \\
\hline & $\begin{array}{l}\text { (+) Initiate language } \\
\text { E.g., make a list; produce a text based on a sample or basic } \\
\text { rhetorical frame }\end{array}$ & 44 & $41,51 \%$ \\
\hline & $\begin{array}{l}\text { (+) Respond } \\
\text { In narrowly defined language/non-verbal response (e.g., } \\
\text { identify picture; true/false; gap-filler; sequence sentences) }\end{array}$ & 31 & $29,25 \%$ \\
\hline & $\begin{array}{l}\text { (-) No action required } \\
\text { E.g., read/listen-no other activity }\end{array}$ & 22 & $20,75 \%$ \\
\hline \multirow[t]{4}{*}{$\mathbf{B}$} & FOCUS & & \\
\hline & $\begin{array}{l}\text { (+) Language system } \\
\text { E.g., practice forms/patterns; apply rules }\end{array}$ & 55 & $51,89 \%$ \\
\hline & $\begin{array}{l}\text { (+) Meaning } \\
\text { E.g., comprehension exercises, no extended L2 output }\end{array}$ & 37 & $34,91 \%$ \\
\hline & $\begin{array}{l}\text { (+) Meaning/Form relationship } \\
\text { E.g., consciousness-raising activity; prepare a report for } \\
\text { presentation to the class }\end{array}$ & 67 & $63,21 \%$ \\
\hline \multirow[t]{9}{*}{$\mathbf{C}$} & OPERATION & & \\
\hline & (+) Repeat/reproduce identically & 29 & $27,36 \%$ \\
\hline & $\begin{array}{l}\text { (-) Repeat/reproduce with substitution } \\
\text { Mechanical drills }\end{array}$ & 13 & $12,26 \%$ \\
\hline & $\begin{array}{l}\text { (+) Repeat/reproduce selectively } \\
\text { Meaningful drills }\end{array}$ & 29 & $27,36 \%$ \\
\hline & $\begin{array}{l}\text { (+) Repeat/reproduce with transformation } \\
\text { E.g., sequence words to form a sentence }\end{array}$ & 43 & $40,57 \%$ \\
\hline & $\begin{array}{l}\text { (+) Repeat/reproduce with expansion } \\
\text { E.g., use a sample dialog but change the setting }\end{array}$ & 43 & $40,57 \%$ \\
\hline & $\begin{array}{l}\text { (+) Build text with recalled items } \\
\text { E.g., produce a list of words/an answer to a question from } \\
\text { memory }\end{array}$ & 52 & $49,06 \%$ \\
\hline & $\begin{array}{l}\text { (+) Apply general knowledge } \\
\text { E.g., use information learned in another subject }\end{array}$ & 64 & $60,38 \%$ \\
\hline & (+) Decode meaning & 3 & $2,83 \%$ \\
\hline
\end{tabular}


Author: Christina Atika Yuliana

\begin{tabular}{|c|c|c|}
\hline Match phrases with meanings in L1 & & \\
\hline (+) Extract gist, information, details & 47 & $44,34 \%$ \\
\hline (+) Categorize selected information & 20 & $18,87 \%$ \\
\hline (+) Hypothesize, infer meaning & 33 & $31,13 \%$ \\
\hline $\begin{array}{l}\text { (+) Compare samples of language on the basis of contents } \\
\text { (meaning) or form } \\
\text { E.g., true/false; select the correct version; whose story was } \\
\text { the most interesting? }\end{array}$ & 16 & $15,09 \%$ \\
\hline $\begin{array}{l}\text { (+) Analyze language form } \\
\text { Examine the component parts of a text/word (e.g., find the } \\
\text { stressed syllable in a word) }\end{array}$ & 17 & $16,04 \%$ \\
\hline $\begin{array}{l}\text { (+) Formulate a language rule } \\
\text { E.g., examine sentences and write partially formulated rule }\end{array}$ & 21 & $19,81 \%$ \\
\hline (+) Apply a language rule & 60 & $56,60 \%$ \\
\hline (+) Negotiate to achieve something & 4 & $3,77 \%$ \\
\hline (+) Review own/peers' L2 output & 46 & $43,40 \%$ \\
\hline $\begin{array}{l}\text { (+) Attend to explanation/example } \\
\text { Students are required to be alert, perhaps notice something. }\end{array}$ & 15 & $14,15 \%$ \\
\hline
\end{tabular}

\section{Who with whom?}

Table 4 presents the results concerning the participation structure done that is inferred from the tasks/activities instructions: with whom interactions are done. Individual work predominates the activities, that $48.11 \%$ of activities in high school textbooks grade XI involved individual work, $41.51 \%$ involve presentation (include present performance, act out dialogues, make poster or any artworks, etc.), $40.57 \%$ pair/group work, and $29.25 \%$ group work with the class (class feedback or answer question session after presentation). It shows that the book seems to offer more opportunities for interaction and meaning negotiation in the L2 since it is more than 
a quarter percent of the whole tasks provided in the book. The book still provides activities that involve teacher and students' interaction for about $22.64 \%$.

Table 4 The Learners' Main Focus of Attention during Tasks

\begin{tabular}{|c|c|c|}
\hline \multicolumn{3}{|l|}{ II. Who with whom? } \\
\hline Aspect & Total & Percentage \\
\hline $\begin{array}{l}\text { (+) Teacher and Students } \\
\text { E.g., teacher-fronted question and answer sessions }\end{array}$ & 24 & $22,64 \%$ \\
\hline $\begin{array}{l}\text { (+) Individual/Pair/Group and Whole class } \\
\text { E.g., after presenting, a group answers questions }\end{array}$ & 31 & $29,25 \%$ \\
\hline (+) Choral work & 0 & $0,00 \%$ \\
\hline (+) Individual work & 51 & $48,11 \%$ \\
\hline $\begin{array}{l}\text { (+) Presentation (e.g., act out a dialog, present a poster } \\
\text { individually, in pairs, or in groups } \\
\text { E.g., act out a dialog; present a poster }\end{array}$ & 44 & $41,51 \%$ \\
\hline (+) Pair/group work, simultaneously & 43 & $40,57 \%$ \\
\hline
\end{tabular}

\section{With what content?}

Table 5 shows the results regarding the contents of the tasks that are assigned to the learners. A staple of language acquisition-rich classrooms is extensive input and output of language in use. In terms of input, it consists $81,13 \%$ predominantly of written words, phrases, sentences, or brief texts. $50 \%$ of the activities consist of non-verbal tasks that involve pictures and sequences. $11,32 \%$ of the input is in written form more than 50 words (texts and passages) with supra-sentential features. However, although the book has been distributed digitally, the book is still lacking of aural input form, both words/phrases/sentence less than 50 words (only 0,94\%)or texts/passages more than 50 words $(0 \%)$.

Similar results emerged for output. The most common type of required output found in the sample was of the restricted, controlled kind in written form of short texts/words/phrases (44.34\%). 29.25\% of the output involve non-verbal form like matching item, check correct picture, draw something, crossword, jigsaw, etc.; and $25.47 \%$ involve written coherent and connected sentence more than 30 words. Different with the input, the output emerged in this book produce more oral activities in L2: $35.85 \%$ oral words/phrases/short texts and $7.55 \%$ oral texts/connected sentence more than 30 words. In order to support language acquisition, more extensive oral input of language in use is required in textbooks, as well as activities eliciting long turns and extended written and oral output.

Last, although the source of the activities and tasks in the book is $73.58 \%$ from the materials and $19.81 \%$ from the teachers; the findings reported in sections B and C indicate that the textbook has already included more activities requiring personal input from learners $(94.34 \%$ and 87.74\%) and involving more contextualized activities that involved daily basis realities (94.34\%). Including activities that require personal input from the learners may increase their motivation 
(Guilloteaux, 2012). Nevertheless, the nature of the activities/tasks that involve metalinguistic information (e.g., a grammatical rule with example sentences; explanations about the use of certain expressions) is only $7.55 \%$.

Table 5 The Contents of the Tasks Assigned to The Learners

\begin{tabular}{|c|c|c|c|}
\hline \multicolumn{4}{|c|}{ III. With what content } \\
\hline & Aspect & Total & Percentage \\
\hline \multirow[t]{13}{*}{$\mathbf{A}$} & FORM & & \\
\hline & Input to learners & & \\
\hline & (+) Non-verbal (e.g., pictures to sequence) & 53 & $50,00 \%$ \\
\hline & (+) Written: words/phrases/short texts $<50$ words & 86 & $81,13 \%$ \\
\hline & (+) Aural: words/phrases/short texts $<50$ words & 1 & $0,94 \%$ \\
\hline & $\begin{array}{l}\text { (+) Written: Coherent text }>50 \text { words with supra- } \\
\text { sentential features }\end{array}$ & 12 & $11,32 \%$ \\
\hline & $\begin{array}{l}\text { (+) Aural: Coherent text }>50 \text { words with supra-sentential } \\
\text { features }\end{array}$ & 0 & $0,00 \%$ \\
\hline & Expected learner output & & \\
\hline & $\begin{array}{l}\text { (+) Non-verbal: e.g., match items, check correct } \\
\text { picture, draw }\end{array}$ & 31 & $29,25 \%$ \\
\hline & $\begin{array}{l}\text { (+) Written words/phrases/single sentence: e.g., fill in } \\
\text { the blanks }\end{array}$ & 47 & $44,34 \%$ \\
\hline & $\begin{array}{l}\text { (+) Oral words/phrases/single sentence: e.g., respond } \\
\text { to a drill }\end{array}$ & 38 & $35,85 \%$ \\
\hline & $\begin{array}{l}\text { (+) Written: Coherent text with connected sentences } \\
\text { >30 words }\end{array}$ & 27 & $25,47 \%$ \\
\hline & $\begin{array}{l}\text { (+) Oral: Coherent text with connected sentences }>30 \\
\text { words }\end{array}$ & 8 & $7,55 \%$ \\
\hline \multirow[t]{4}{*}{ B } & SOURCE & & \\
\hline & (+) Materials (dialog/text). & 78 & $73,58 \%$ \\
\hline & (+) Teacher & 21 & $19,81 \%$ \\
\hline & (+) Learners (e.g., present results of own research) & 100 & $94,34 \%$ \\
\hline \multirow[t]{5}{*}{ C } & NATURE & & \\
\hline & $\begin{array}{l}\text { (+) Metalinguistic information (e.g., a grammatical } \\
\text { rule with example sentences; explanations about the } \\
\text { use of certain expressions) }\end{array}$ & 8 & $7,55 \%$ \\
\hline & (+) Non-fiction & 100 & $94,34 \%$ \\
\hline & (+) Fiction & 9 & $8,49 \%$ \\
\hline & (+) Learners' personal information/opinion & 93 & $87,74 \%$ \\
\hline
\end{tabular}




\section{CONCLUSION}

The present study framework done by (Guilloteaux, 2012) has illustrated how a minimally modified version of Littlejohn's $(1998,2011)$ task analysis schedule could be used as an operational framework to evaluate whether textbooks reflect universal SLA criteria which were mainly derived from Ellis' (2005) list of ten general principles for instructed SLA and SLA-based principles for materials design from Cook (1998), Richards (2006), Tomlinson (2010), and Tomlinson and Masuhara (2010). From this study, it can be concluded that there is evidence to suggest that the English textbook for Senior High School Grade XI (year 2) established by the Ministry of Education and Culture entitled Bahasa Inggris reflect SLA principles. However, the extent to which textbooks actually do support language acquisition can only be determined through in-use evaluation. For suggestion, since the book can be distributed digitally, it is better to take the advantage of technology use by adding aural input and oral output activities/tasks.

\section{REFERENCES}

Cook, V. (1998). Relating SLA research to language teaching materials. Canadian Journal of Applied Linguistics (CJAL)/ Revue Canadienne de Linguistique Applique'e (RCLA), 1(12), 9-27.

Cook, V. (2008). Second language learning and language teaching. London, UK: Hodder Education.

Garinger, D. (2002, December 02). Textbook Selection for ESL Classroom. Retrieved from Eric Digest: https://www.ericdigests.org/

Guilloteaux, M. J. (2012, November). Language Textbook Selection: Using Materials Analysis from the Perspective of SLA Principles. The Asia-Pacific Education. doi:10.1007/s40299012-0015-3

Littlejohn, A. (1992). Why are English language teaching materials the way they are? Doctoral dissertation, University of Lancaster, England. Retrieved from http://www.andrewlittlejohn.net/web site/books/phd.html

Richards, J. C. (2001). The Role of Textbooks in a Language Program. Cambridge, UK: Cambridge University Press.

Tomlinson, B. (1998). Materials development in language teaching. United Kingdom: Cambridge University Press.

Tomlinson, B. (2008). Language acquisition and language learning materials. In B. Tomlinson (Ed.), English language learning materials: A critical review (pp. 3-13). London: Continuum.

Tomlinson, B. (2010). Principles of effective materials development. In N. Harwood (Ed.), English language teaching materials: Theory and practice (pp. 81-108). Cambridge, UK: Cambridge University Press. 
Tomlinson, B. (2011). Introduction: Principles and procedures of materials development. In B. Tomlinson (Ed.), Materials development in English teaching (2nd ed., pp. 1-34). Cambridge, UK: Cambridge University Press.

Waters, A. (2009). Advances in materials design. In M. H. Long \& C. J. Doughty (Eds.), Handbook of language teaching (pp. 311-326). Malden, MA: Blackwell. 